\title{
RANCANG BANGUN APLIKASI KAMUS SUNDA-INDONESIA DENGAN METODE BINARY SEARCH BERBASIS ANDROID
}

\author{
Dinar Sugiri \\ dinar.sugiri@student.unsika.ac.id \\ Program Studi Teknik Informatika \\ Fakultas Ilmu Komputer \\ Universitas Singaperbangsa \\ Karawang.
}

\author{
Hanny Hikmayanti \\ hanny.hikmayanti@staff.unsika.ac.id \\ Teknik Informatika Universitas \\ Singaperbangsa Karawang. \\ Jl. H.S. Ronggo Waluyo / Teluk Jambe \\ Karawang
}

\author{
Aries Suharso \\ aries.suharso@unsika.ac.id \\ Teknik Informatika Universitas \\ Singaperbangsa Karawang. \\ J1. H.S. Ronggo Waluyo / Teluk \\ Jambe Karawang
}

\begin{abstract}
ABSTRAK
Bahasa merupakan jembatan untuk berkomunikasi. Di dunia ini banyak bahasa salah satunya adalah bahasa Indonesia, sebagai bahasa Nasional negara Indonesia. Tetapi banyak bahasa dari bagian daerah lain yang digunakan untuk berkomunikasi diantaranya adalah bahasa Sunda. Bahasa Sunda adalah bahasa "Ibu" bagi masyarakat Jawa Barat. Bahasa Sunda terutama dipertuturkan di sebelah barat pulau Jawa, di daerah yang dijuluki Tatar Sunda / Pasundan. Banyak sekali buku kamus bahasa sunda yang beredar tetapi buku tersebut justru menyulitkan karena pengguna harus mencari arti dari suatu kata di kamus secara manual, membuka perlembar dari kamus bahasa sunda, memakan waktu yang cukup lama dan kamus secara manual tidak dapat mengikuti perkembangan teknologi yang ada pada saat ini. Berdasarkan masalah yang di dapatkan, akan di buat sebuah penelitian untuk merancang perangkat lunak Kamus sundaIndonesia dengan metode binary search berbasis android. Diharapkan dengan adanya teknologi di masyarakat aplikasi kamus sunda indonesia ini dapat mempermudah dalam pencarian kata bahasa sunda. Tahapan penelitian menggunakan Metodologi SDLC dengan pendekatan prototipe yang tahapannya adalah identifikasi kebuthan pemakai, membuat prototipe, menguji prototipe, memperbaiki prototipe, pengembangan versi produksi, perangkat lunak ini beroperasi pada smartphone android minimum SDK jelly been. Tools yang digunakan untuk membuat perangkat lunak kamus sunda indonesia yaitu ADT Android studio, Hasil penelitian ini yaitu rancang bangun aplikasi kamus sunda-indonesia dengan metode binary search berbasis android yand di lengkapi dengan terjemahan, kalimat,inputan kata untuk menambah kosa kata pada kamus dan tentang aplikasi yang memberi informasi kamus sunda- indonesia.
\end{abstract}

Kata kunci : Kamus sunda-indonesia, Android ,DIA,Star UML,Vsio 2007, ADT Android Studio.

\section{PENDAHULUAN}

Teknologi komunikasi khususnya teknologi smartphone telah menciptakan sebuah perubahan besar dalam dunia komunikasi. Perkembangan yang pesat dari perangkat teknologi ini telah memunculkan beragamnya fungsi baru selain fungsi utamanya sebagai sebuah alat komunikasi. Selain itu smartphone pun sudah di anggap sebagai alat kebutuhan sehari-hari, karena smartphone dapat diperoleh dengan mudah dan murah. Perangkat smartphone yang merupakan salah satu media komunikasi menjadi bagian dari kebutuhan masyarakat bahkan perangkat smartphone menjadi suatu benda yang lumrah, karena peredarannya yang sangat luas dan mudah dipakai.

Dengan semakin majunya teknologi dan informasi saat ini. Bahasa merupakan jembatan untuk berkomunikasi. Di dunia ini banyak bahasa salah satunya adalah bahasa Indonesia, sebagai bahasa Nasional negara Indonesia. Tetapi banyak bahasa dari bagian daerah lain yang digunakan untuk berkomunikasi diantaranya adalah bahasa Sunda. Bahasa Sunda adalah bahasa "Ibu" bagi masyarakat Jawa Barat. Bahasa Sunda terutama dipertuturkan di sebelah barat pulau Jawa, di daerah yang dijuluki Tatar Sunda / Pasundan.

Permasalahannya yang ada pada saat ini bahasa sunda memiliki bahasa yang kasar yang biasa digunakan dengan teman sebaya atau bahasa yang sopan yang digunakan untuk orang yang lebih tua dari pengguna bahasa yang terkadang kurang dimengerti oleh orang awam pada umumnya. Banyak sekali buku kamus bahasa sunda yang beredar tetapi buku tersebut justru menyulitkan karena pengguna harus mencari arti dari suatu kata di kamus secara manual, membuka perlembar dari kamus bahasa sunda, memakan waktu yang cukup lama dan kamus secara manual tidak dapat mengikuti perkembangan teknologi yang ada pada saat ini. Tapi dengan teknologi dizaman sekarang segala informasi bisa berkembang dengan sangat cepat. Untuk itu diperlukan adanya kamus bahasa sunda, agar dapat memudahkan orang awam dalam memahami arti-arti kata dalam bahasa sunda.

Dengan kemajuan teknologi yang sangat pesat pada saat ini dibutuhkan sebuah aplikasi yang dapat memenuhi kebutuhan setiap pengguna akan sebuah aplikasi pengganti buku yang mudah dibawa serta dapat digunakan kapanpun dan dimanapun.

Oleh karena itu Aplikasi Kamus Indonesia-Sunda berbasis Android dirancang sebagai 
pengganti buku kamus yang masih manual dan memudahkan pengguna dalam berbahasa sunda. dalam berbahasa Sunda. Sebagai alat komunikasi, Bahasa Sunda digunakan untuk bertukar pesan (pikiran, perasaan dan keinginan) baik lisan maupun tulisan, menyertai berbagai segi kehidupan masyarakat penuturnya.

Di dalam Aplikasi kamus Indonesia-Sunda ini dibuat sederhana mungkin agar mudah dalam pengaksesannya, dan proses penerjemahannya menggunakan metode binary search untuk mempermudah pencarian kata dalam basis datanya.

\section{LANDASAN TEORI}

Apabila kata dalam proses pencariannya tidak ditemukan maka akan di tampilkan pilihan kata- kata yang dianggap sepadan.

Berdasarkan uraian latar belakang diatas, Penulis bermaksud merancang sebuah aplikasi Kamus Bahasa Sunda berbasis Android. Oleh karena tema yang di ambil penulis adalah sistem informasi dimana aplikasi yang di rancang berbentuk informasi berupa sebuah kamus elektronik yang ada pada teknologi handphone berbasis android. Dari tema di atas penulis memilih topik "RANCANG BANGUN APLIKASI KAMUS INDONESIA-SUNDA DENGAN METODE BINARY SEARCH BERBASIS ANDROID”.

\subsection{Kamus}

Ada banyak macam kamus. Menurut bahasa yang digunakan, kamus bisa dibedakan menjadi kamus ekabahasa, kamus dwibahasal dan kamus aneka bahasa. Kamus eka bahasa adalah kamus yang hanya menggunakan satu bahasa saja. contohnya adalah Oxford Advanced Dictionarv Kainus. Umum Bahasa Indonesia, Bahasa Jawa. dan lain-lain. Kamus dwibahasa menggunakan dua bahasa, contohnya adalah Kamus Indonesia-Inggris, karangan John M. Echols dan Hassan Shadily. Sedangkan kamus aneka bahasa bersifat danan kata atau keterangan tentang kata aran di dalarn dua bahasa atau lebih. Contohnya adalah kamus bahasa Inggris-lndonesia-Arab. Yang perlu diperhatikan oleh penerjemah adalah kamus dwibahasa dan anekabahasa tidak selalu sesuai untuk menekan makna suatu kata karena makna kata di dalam satu bahasa tidak sama benar dengan makna kata dalam bahasa lain.

Berdasarkan isinya, kamus bisa dibedakan menjadi dua: kamus umum dan kamus khusus. Kamus umum adalah kamus yang berisi keterangan mengenai kata aran. contohnya Kamus Besar Bahasa Indonesia dan Kamus Oxfòrd. Sedangkan kamus khusus adalah kamus yang berisi keterangan kata aran dalam bidang tertentu, misalnya kamus teknik, kamus perminyakan,kamus kedokteran, dan kamus biologi. Memilik bahasanya, kamus umum dan khusus ini bisa berupa kamus ekabahasa, dwibahasa, dan anekabahasa (Zuchridin Suryawinata, 2003).

\subsection{Bahasa}

Bahasa bukanlah sekadar kata-kata lepas tanpa kaitan apapun dengan kebudayaan penuturnya. Sebaliknya, bahasa adalah cerminan kebudayaan masyarakat penuturnya, yang terusmenerus berkembang sesuai dengan tahap-tahap historis dalam masyarakat tersebut. (Hardjono, 1999)

\subsection{Bahasa Sunda}

Bahasa Sunda adalah sebuah bahasa dari cabang Melayu-Polinesia dalam rumpun bahasa Austronesia. Bukti bahwa bahasa Sunda termasuk rumpun Austronesia, di antaranya terdapat kata Lisung (Lesung) dalam bahasa Sunda, lesung (Jawa), lisuh (Kawi), lesong (Madura), lisong (Dayak), losong (Tagalog) .Kata kelingking dalam bahasa Indonesia, kelingking (Malay), kingking (Maanjan), kingki (Sakalava Malagasy), kingking (Proto-Austronesia). Kata gunting dalam bahasa Sunda disebut gunting pula dalam bahasa Tagalog. Selain itu, walaupun bahasa Sunda tidak serumpun dengan bahasa Jepang, tetapi disebabkan oleh migrasi manusia dari selatan termasuk Indonesia ke Jepang terdapat pula kata campur dalam bahasa Sunda digunakan kata champon dalam bahasa Jepang.

Indonesia memiliki keberanekaragaman budaya dan bahasa, setiap wilayah memiliki keunikan masing-masing. Terutama bahasa di dalam satu lingkungan Tatar Sunda pun banyak sekali perbedaan. Perbedaan tersebut berada dalam tataran fonologi, tataran makna suatu kata atau kalimat. Bahasa yang berlaku dalam satu daerah masyarakat bahasa saja disebut bahasa dialek atau bahasa wewengkon, sedangkan bahasa Sunda standar disebut bahasa Sunda lulugu.

Sesuai dengan luasnya wilayah Tatar Sunda, sebelah barat mulai dari wilayah Banten, selatan Banjar dengan perbatasan Cilacap, sebelah timur sampai Kali Pemali (Cipamali) di wilayah 
Brebes, maka bahasa dialek pun sangat banyak mulai dari bahasa Sunda dialek Banten, dialek Kuningan, dialek Ciamis, dialek Cirebon, dialek Sumedang, dialek Karawang, dan sebagainya. Para pakar lain berpendapat bahwa bahasa Sunda dibedakan menjadi enam dialek yaitu dialek barat, dialek utara, dialek selatan, dialek tengah timur, dialek timur laut, dan dialek tenggara. Dialek Barat dipertuturkan di daerah Banten selatan. Dialek Utara mencakup daerah Sunda utara termasuk kota Bogor dan beberapa bagian Pantura. Lalu dialek Selatan adalah dialek Priangan yang mencakup kota Bandung dan sekitarnya. Sementara itu dialek Tengah Timur adalah dialek di sekitar Majalengka. Dialek Timur Laut adalah dialek di sekitar Kuningan, dialek ini juga dipertuturkan di beberapa bagian Brebes, Jawa Tengah. Akhirnya dialek Tenggara adalah dialek sekitar Ciamis. (Prawirasumantri, 2007).

\subsection{Sejarah Perkembangan bahasa Sunda}

Pepatah mengatakan "bahasa menunjukkan bangsa". Dari pepatah tersebut dapat diinterpretasikan bahwa bahasa satu bangsa atau satu suku bangsa mencerminkan budaya masyarakat tersebut. Bahasa pada satu waktu merupakan perwujudan budaya pada waktu tersebut. Untuk Jawa Barat Kosoh et al. (1995: xi) membagi zaman menjadi tujuh (7) waktu, yaitu zaman Prasejarah ( \pm abad ke-1 Masehi), zaman Kuna ( \pm abad ke-1 sampai 15 Masehi), zaman Jawa Barat pada masa masuknya dan berkembangnya Islam, Jawa Barat dalam abad ke-19 $( \pm 1800$ $1900)$, zaman kebangkitan nasional $( \pm 1900-1942)$, zaman pendudukan Jepang, dan zaman Kemerdekaan. Kaitan antara pembagian zaman di atas, Prawirasumantri (2007: 11) secara garis besar membagi sejarah bahasa Sunda menjadi:

1. Sejarah bahasa Sunda masa I (sebelum tahun 1600 Masehi);

2. Sejarah bahasa Sunda masa II ( 1600-1800 Masehi);

3. Sejarah bahasa Sunda masa III (1800-1900 Masehi);

4. Sejarah bahasa Sunda masa IV ( 1900-1945 Masehi);

5. Sejarah bahasa Sunda masa V( 1945-sekarang).

Sesuai dengan tema penelitian ini, penulis membagi sejarah bahasa Sunda menjadi tiga zaman, yaitu bahasa Sunda masa lampau (sebelum tahun 1600-1945), bahasa Sunda masa kini (1945-sekarang), dan bahasa Sunda masa yang akan datang. (Prawirasumantri, 2007)

\subsection{Binary Search}

Metode Binary Search atau sering pula dinamakan pencarian biner, hanya digunakan untuk pencarian data pada array yang sudah terurut. Berikut tahap-tahap pada algoritma Binary Search :

1. Data diambil dari posisi 1 sampai ke posisi akhir $\mathrm{N}$

2. Kemudian cari posisi data tengah dengan rumus: ( posisi awal + posisi akhir) $/ 2$

3. Kemudian data yang di cari di bandingkan dengan data yang di tengah apakah sama atau lebih kecil, atau lebih besar.

4. Jika lebih besar, maka proses pencarian dicari dengan posisi awal adalah posisi tengah+1

5. Jika lebih kecil, maka proses pencarian dicari dengan posisi akhir adalah posisi tengah -1

6. Jika data sama, Berarti data di temukan.

\subsection{Java}

Java adalah bahasa pemograman yang berorientasi objek (OOP) dan dapat dijalankan pada berbagai platform sistem operasi. Java bermula dan proyek penelitian perusahaan Sun Microsystems dengan nama sandi Green pada tahun 1991. Terdapat prediksi bahwa mikroprosesor akan digunakan tuas pada peralatan-peralatan elektronik. Karena adanya bermacam tipe mikroprosesor, maka dibutuhkan sebuah bahasa pemrograman yang dapat berjalan di semua mikroprosesor.

Terciptalah sebuah bahasa pemrograman baru. Oleh James Gosling, yaitu salah satu orang yang berperan besar dalam proyek tersebut, program ini diberi name Oak. Sesuai dengen pohon Oak yang tumbuh dan bisa dilihat melalui jendela kerjanya di Sun Microsystems. Selang beberapa waktu kemudian, ditemukan bahwa sudah ada bahasa pemrograman dengan nama Oak. Akhimya setelah beberapa pegawai Sun mengunjungi sebuah kedai kopi, nama bahasa pemrograman ini diganti dengan Java. Java merupakan salah satu jenis biji kopi yang ada di kedai tersebut, yaitu biji kopi Jawa. Sun Microsystems mengumumkan kehadiran bahasa Java secara format di tahun 1995. Bahasa mi mutai disambut hangat masyarakat tuas seiring dengan meledaknya era internet (Rachma Hakim S, 2009).

\subsection{Android Studio}

Android Studio adalah sebuah IDE yang bisa digunakan untuk pengembangan aplikasi 
Android, dan dikembangkan oleh Google. Android Studio merupakan pengembangan dari Eclipse IDE, dan dibuat berdasarkan IDE Java populer, yaitu Intell IDEA. Android Studio direncanakan untuk menggantikan Eclipse ke depannya sebagai IDE resmi untuk pengembangan aplikasi Android. Sebagai pengembangan dari Eclipse, Android Studio mempunyai banyak fitur-fitur baru dibandingkan dengan Eclipse IDE. Berbeda dengan Eclipse yang menggunakan Ant, Android Studio menggunakan Gradle sebagai build environment. Fitur-fitur lainnya adalah sebagai berikut :

1. Menggunakan Gradle-based build system yang fleksibel.

2. Bisa mem-build multiple APK .

3. Template support untuk Google Services dan berbagai macam tipe perangkat.

4. Layout editor yang lebih bagus.

5. Built-in support untuk Google could Platfrom, sehingga mudah untuk integrasi dengan Google Cloud Messaging dan App Engine.

6. Import library langsung dari Maven repository (geber)

\subsection{Sistem Operasi Android}

Sistem operasi Android adalah sebuah sistem operasi untuk perangkat mobile berbasis linux yang mencakup sistem operasi, middleware, dan aplikasi (Safaat, 2014:1). Platform android bermula dari nama sebuah perusahaan yang berkecimpung di dunia IT \& Communication khususnya bergerak dalam bidang perangkat lunak dengan nama Android Inc. yang kemudian seluruh sahamnya dibeli oleh perusahaan raksasa yaitu Google Inc., setelah itu dibentuklah Open Handset Alliance, yaitu konsorsium dari 34 perusahaan piranti keras, piranti lunak dan telekomunikasi termasuk di dalamnya yaitu : Google, HTC, Intel, Motorola, Qualcomm, $\mathrm{T}$ - Mobile dan invidia. Adapaun ikon dari sistem operasi Android ini sering disebut juga dengan sebutan robot hijau.

\subsection{Perkembangan Sistem Android}

Dari perkembangan sistem operasi Android ini yang sekarang menjadi sangat populer karena bersifat open source menjadikannya sebagai sistem operasi yang banyak diminati oleh banyak pengguna. Adapun berberapa kelebihan dari sistem operasi Android adalah sebagai berikut (Safaat, 2014:3) :

1. Lengkap (Complete Platform)

Para desainer dapat melakukan pendekatan yang komprehensif ketika mereka sedang mengembangkan platform android. Android merupakan sistem operasi yang aman dan banyak menyediakan tools dalam membangun software dan memungkinkan untuk peluang pengembangan aplikasi.

2. Terbuka (Open Source Platform)

Platform Android yang bersifat open source menjadikan sistem operasi ini mudah dikembangkan oleh para developer karena bersifat terbuka. Android sendiri menggunakan Linux Kernel 2.6.

3. Bebas (Free Platform)

Developer dengan bebas bisa mengembangkan, mendistribusikan dan memperdagangkan sistem operasi Android tanpa harus membayar royalti untuk mendapatkan license.

\section{OBJEK DAN METODOLOGI PENELITIAN}

\subsection{Objek Penelitian}

Kamus adaah sejenis buku rujukan yang menerangkan makna kata-kata. Kamus berfungsi untuk membantu seseorang mengenal perkataan baru. Selain menerangkan maksud kata, kamus juga mungkin mempunyai pedoman sebutan, asal-usul (etimologi) sesuatu perkataan dan juga contoh penggunaan bagi sesuatu perkataan. Untuk memperjelas kadang kala terdapat juga ilustrasi di dalam kamus. Kata kamus diserap dari bahasa Arab qamus, dengan bentuk jamaknya qawamis. Kata Arab itu sendiri berasal dari kata Yunani okeanos yang berarti 'lautan'. Sejarah kata itu jelas memperlihatkan makna dasar yang terkandung dalam kata kamus, yaitu wadah pengetahuan, khususnya pengetahuan bahasa, yang tidak terhingga dalam dan luasnya. Kamus merupakan khazanah yang memuat perbendaharaan kata suatu bahasa, yang secara ideal tidak terbatas jumlahnya. Setiap kebudayaan besar di dunia bangga akan kamus bahasanya. Dalam kenyataannya kamus itu tidak hanya menjadi lambang kebanggaan suatu bangsa, tetapi juga mempunyai fungsi yaitu:

1. Menemukan makna sebuah kata

2. Menemukan makna sebuah kata

3. Menetapkan palafalan dan cara pengucapan 
4. Menetapkan ejaan

5. Menelusuri asal asul sebuah kata

6. Membedakan antara kata yang tak lazim dan tak terpakai serta menjelaskan kata-kata yang murni dan serapan

7. Mengetahui sinonim dan antonim

8. Penggunaan kata-kata sastra dan peribahasa

9. Pengetahuan yang bersifat ensiklopedia.

\subsection{Metodologi Penelitian}

Metode yang digunakan pada metodologi penelitian ini yaitu metode Software Developmet Life Cycle (SDLC) dengan model prototype. Dengan menggunakan model prototype penulis dapat mengetahui spesifikasi kebutuhan pelanggan secara lebih detail dan model prototype cocok untuk pembuatan aplikasi kecil.

\subsection{Rancangan Penelitian}

Dalam rancanagan penelitian ini, hasil akhir yang akan dilakukan yaitu berupa Aplikasi dengan metode penelitian Sofware Development Life Cycle (SDLC) dengan model prototype dengan tahapan yang terurut. Adapun langkah-langkah rancangan penelitiannya dari pengembangan prototype yang akan penulis lakukan adalah sebagai berikut :

1. Mengidentifikasi kebutuhan pemakai

2. Membuat sebuah prototype

3. Menguji Prototipe

4. Memperbaiki dan meningkatkan prototype

5. Mengembangka versi produksi

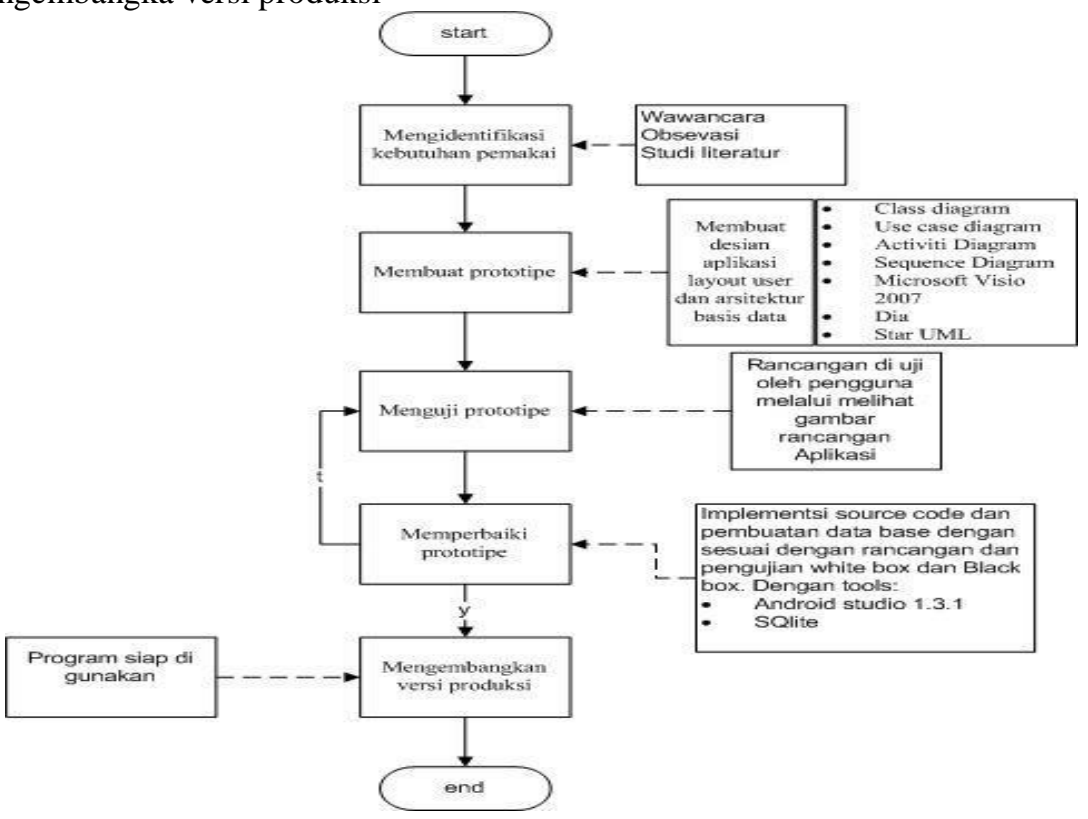

Gambar 3. 1 Ilustrasi rancangan penelitian Menggunakan model prototype (kadir, 2014)

\subsection{Mengidentifikasi Kebutuhan-Kebutuhan Pemakai}

Penulis akan mengidentifikasi kebutuhan user, supaya penulis bisa merancang sistem yang akan dibangun sesuai dengan yang diharapkan user. Sebelum pada tahap perancangan, penulis akan memulai pada tahap awal terlebih dahulu yaitu penulis akan menganalisis sistem dengan cara melakukan mengumpulkan data yaitu dengan field reserch (metode penelitian)/observasi, dan interview (wawancara) dan dengan cara literatur yaitu dengan dokumentasi terhadap kebutuhan yang diinginkan pemakai, baik dalam model interface, teknik, prosedural maupun dalam teknologi yang akan digunakan. Dalam tahap ini di lakukan wawancara kepada guru bidang bahasa Sunda.

\subsection{Membuat Sebuah Prototipe}

Setelah mendapakan kebutuhan pengguna maka akan dilanjutkan pada tahap kedua yaitu membuat prototype, penulis akan membuat prototype sistem tersebut untuk memperlihatkan kepada pemakai model sistem yang akan dirancang. Pada tahap ini akan dilakukan beberapa tahap sebagaim berikut:

1. Desain Arsitektur Aplikasi

Untuk membuat model desain arsitektur aplikasi dilakukan dirancang dengan menggunakan 
diagram UML yaitu meliputi : Class Diagram, Activity Diagram, Use Case Diagram dan Squence Diagram, dengan tool yang akan digunakan yaitu Microsoft Visio 2007

2. Desain Database

Dengan pemodelan database ini menggunakan Class Diagram, dengan tool yang akan digunakan yaitu Microsoft Visio 2007.

3. Desain Interface

Agar pengguna dapat terbayang dengan aplikasi yang akan dibuat, maka dirancang desain interface, dengan tool yang akan digunakan yaitu Microsoft Visio 2007, Dia, Star UML

\subsection{Menguji Prototipe}

Pada tahap ketiga yaitu pengujian prototipe, penulis akan melakukan uji coba sistem yang telah dirancang untuk memastikan bahwa sistem tersebut dapat digunakan dengan baik dan benar, sesuai kebutuhan pemakai

\subsection{Memperbaiki Dan Meningkatkan Prototipe}

Pada tahap keempat yaitu memperbaiki prototipe, penulis akan menentukan apakah sistem tersebut dapat diterima oleh pemakai, atau harus dilakukan beberapa perbaikan atau bahkan dibongkar semuanya dan mulai dari awal lagi, dan setelah perbaikan sistem itu selesai dikerjakan, penulis akan kembali lagi pada tahap yang ketiga yaitu dengan melakukan pengujian prototipe kembali. Pada tahap ini script program android dengan menggunakan tool Android studio1.3.1, SDK API 17 android 4.2 (Jelly Bean) dengan bahasa pemograman Java. Setelah pembuatan script program lanjut ke tahap pembuatan database mengguanakan SQLite, maka data- data yang diperlukan akan tersimpan pada database. Hasil dari tahap ini berupa program aplikasi dan sekaligus melakukan pengujian White Box dan Black Box.

Setelah dilakukan tahap testing (pengujian) whitebox testing dan blackbox testing. Maka dilakukan evaluasi, apabila dalam pengujiannya masih belum sempurna atau belum sesuai dengan kebutuhan pengguna, maka kembali ke tahap membuat prototipe dan dilanjutkan ke tahap berikutnya. Hasil dari tahap ini yaitu testing kelayakan pengguna, maka jika sudah sempurna lanjut pada tahap mengembangkan Versi Produk

\subsection{Mengembangkan Versi produk}

Pada tahap kelima, tahap terakhir yaitu mengembangkan versi produksi, penulis akan menyelesaikan sesuai dengan masukan terakhir dari pemakai dan memberikan gambaran bagaimana penggunaan sistem tersebut kepada pemakai setelah sistem tersebut disetujui.

\section{HASIL DAN PEMBAHASAN}

\subsection{Identifikasi Kebutuhan}

Disini dilakukan penguaraian suatu sistem untuk mengidentifikasi dan mengevaluasi permasalahan. Identifikasi kebutuhan pengguna ini dilakukan untuk mendapatkan pemahaman secara keseluruhan mengenai perangkat lunak yang akan di buat berdasarkan kebutuhan dan keinginan pengguna.

Pendefinisian masalah yang didapatkan dari hasil pengumpulan data terhadap objek penelitian adalah :

1. Pada kamus manual kesulitan dalam mencari indexs kata

2. Kebanyakan orang sudah enggan membawa kamus dalam bentuk hard copy

3. Lambat dalam pencarian kata

\subsection{Pendefinisian Masalah}

Pendefinisian masalah yang didapatkan dari hasil pengumpulan data terhadap objek penelitian dan hasil review penelitian sebelumnya adalah :

1. Bagaimana membangun aplikasi kamu menggunakan metode binary search?

2. Bagaimana menerapkan metode binay search?

3. Bagaimana menguji aplikasi kamus Sunda-Indonesia berbasis android?

\subsection{Membuat Prototype}

Dalam pengembangan prototype digambarkan alur sistem berdasarkan kebutuhan pengguna yang ditujukan untuk memberikan pemahaman kepada pengguna mengenai sistem yang akan berjalan pada perangkat lunak yang dibuat.

\subsection{Desain Software}

Dalam membangun sebuah aplikasi, perlu adanya desain software yang berguna untuk memahami aplikasi yang akan dibangun, yang berupa struktur ataupun pemodelan.

1. UML

a. Use Case Diagram

Pembuatan model untuk aplikasi kamus Sunda-Indonesia menggunakan UML, peneliti 
mendeskripsikan alat dari sistem yang akan dibuat dengan model Use Case. Use Case mendeskripsikan fungsi dan aliran data yang terdapat pada sistem.

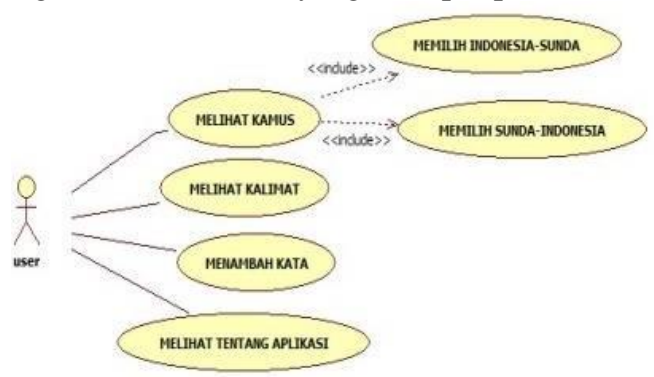

Gambar 4. 1 Use Case Diagram Kamus Sunda-Indonesia

Skenario Use ase

Aktor : Pengguna

Skenario: Kamus

Tabel 4. 1 Sknario Use case melihat Kamus

\begin{tabular}{|l|l|}
\hline \multicolumn{1}{|c|}{ PENGGUNA } & \multicolumn{1}{c|}{ SISTEM } \\
\hline 1. Pengguna membuka menu kamus & \\
\hline & $\begin{array}{l}\text { 2. Aplikasi menampilkan halaman menu } \\
\text { kamus dengan pilihan bahasa }\end{array}$ \\
\hline
\end{tabular}

Tabel 4. 2 Sknario Use case melihat Kamus lanjutan

\begin{tabular}{|l|ll|}
\hline \multicolumn{1}{|c|}{ PENGGUNA } & \multicolumn{1}{|c|}{ SISTEM } \\
\hline $\begin{array}{l}\text { 1. Pengguna memilih bahasa dan memasukan } \\
\text { kata yang ingin di terjemahkan. }\end{array}$ & $\begin{array}{l}\text { 2. Aplikasi menerjemahkan kata yang di } \\
\text { masukan }\end{array}$ \\
\hline
\end{tabular}

Aktor : Pengguna

Skenario : Kalimat

Tabel 4. 3 Use case melihat Kalimat

\begin{tabular}{|c|c|}
\hline PENGGUNA & SISTEM \\
\hline 1.Pengguna membuka menu Kalimat & \\
\hline & 2.Aplikasi menampilkan kalimat sunda \\
\hline
\end{tabular}

Aktor : Pengguna

Skenario : Tambahkan kata

Tabel 4. 4 Usa case melihat Tambah kata

\begin{tabular}{|c|c|}
\hline PENG & SISTEM \\
\hline \multicolumn{2}{|l|}{ 1. Pengguna membuka menu input kata } \\
\hline & $\begin{array}{l}\text { 2. Aplikasi menampilkan menu } \\
\text { tambahkan kata }\end{array}$ \\
\hline \multicolumn{2}{|l|}{ 3. Pengguna Masukan kata } \\
\hline & 4. Aplikasi menyimpan kata \\
\hline
\end{tabular}

Aktor : Pengguna

Skenario : Tentang aplikasi

Tabel 4. 5 Use Case melihat Tentang aplikasi

\begin{tabular}{|l|ll|}
\hline \multicolumn{1}{|c|}{ PENGGUNA } & \multicolumn{1}{|c|}{ SISTEM } \\
\hline $\begin{array}{l}\text { 1. Pengguna membuka menu tentang } \\
\text { aplikasi }\end{array}$ & $\begin{array}{l}\text { 2. Aplikasi menampilkan informasi } \\
\text { penggunaan }\end{array}$ \\
\hline
\end{tabular}

b. Activity Diagram

Dalam activity diagram mendeskripsikan mengenai aliran aktivitas dari proses sistem. Berikut merupakan sub menu Kamus yang berjalan dalam activity diagram, dimana pengguna membuka aplikasi untuk mengakses isi dari sub menu kamus. 


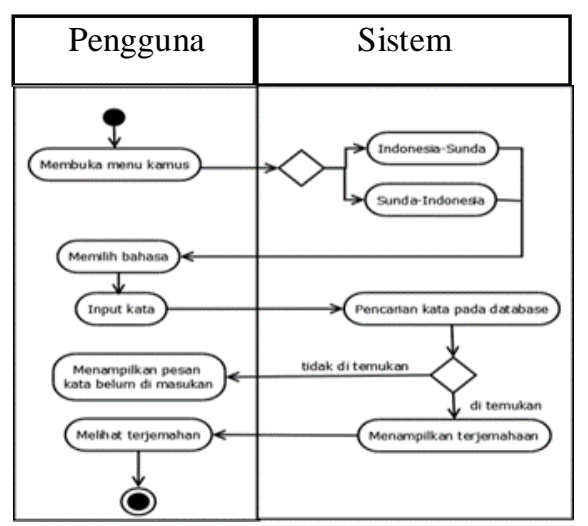

Gambar 4. 2 Activity Diagram melihat Kamus

Activity selanjutnya merupakan aliran aktivitas untuk mengakses menu kalimat, dimana pengguna dapat melihat kalimat sunda.

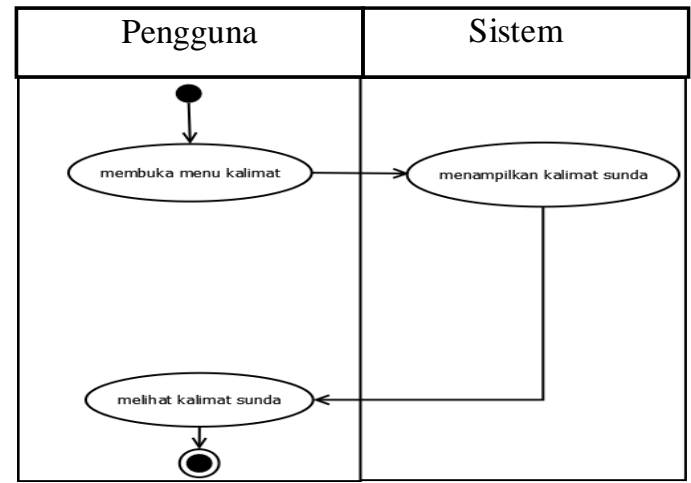

Gambar 4. 3 Activity Diagram melihat kalimat

Activity selanjutnya merupakan aliran aktivitas untuk mengakses menu tambah kata, dimana pengguna dapat menambahkan kata pada kamus.

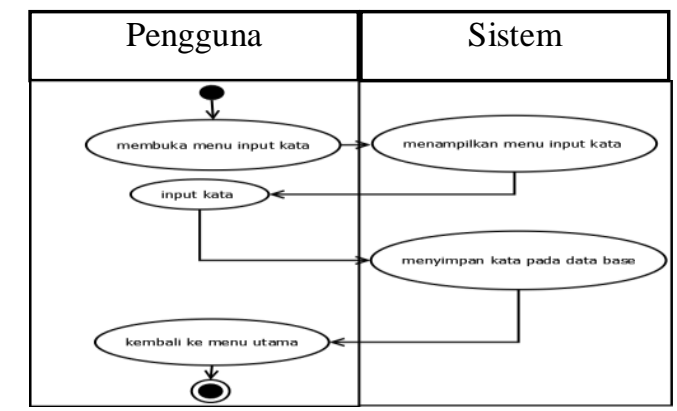

Gambar 4. 4 Activity Diagram menambah kata

Activity selanjutnya merupakan aliran aktivitas untuk mengakses menu tentang aplikasi, dimana pengguna dapat melihat informasi tentang aplikasi

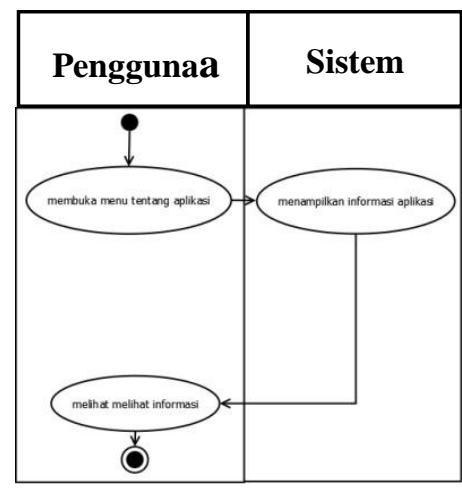

Gambar 4. 5 Activity Diagram menu melihat tentang aplikasi 


\section{c. Sequence Diagram}

Sequence diagram menggambarkan interaksi antara objek disekitar sistem, berikut merupakan diagram sequence dari diagram sequence melihat kamus,diagram sequence melihat kalimat, diagram sequence menambah kata dan diagram sequence melihat tentang aplikasi yang tersaji pada gambar 4.6 sampai dengan 4.9.

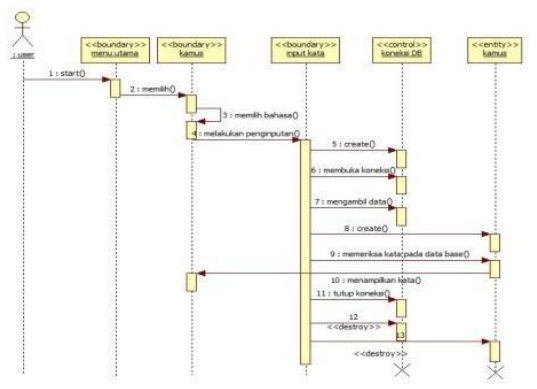

Gambar 4. 6 Diagram Sequence melihat Kamus

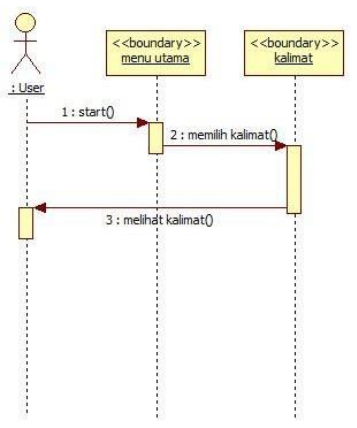

Gambar 4. 7 sequence diagram melihat kalimat

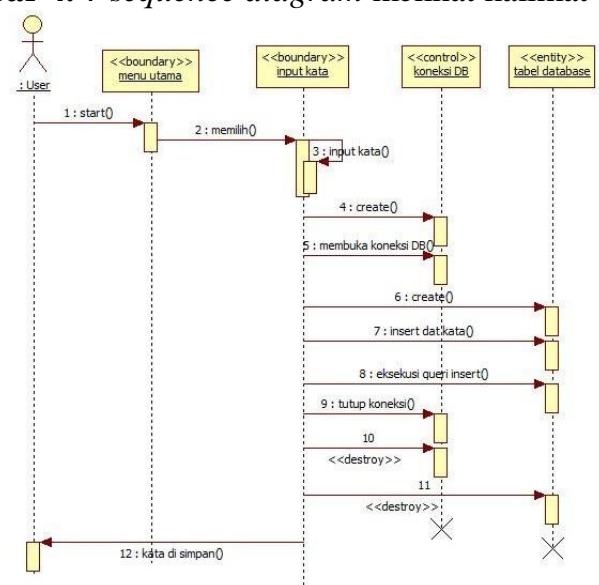

Gambar 4. 8 Diagram Sequence menambah Kata

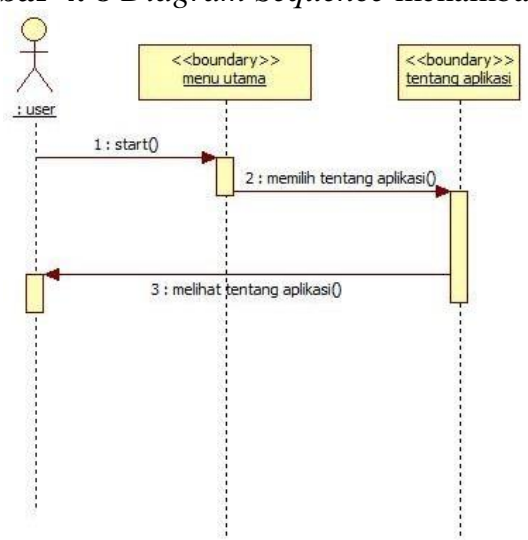

Gambar 4.9 Diagram Sequence melihat Tentang Aplikasi 


\section{d. Class Diagram}

Class diagram memanfaatkan untuk mendeskripsikan jenis-jenis objek dalam suatu system, class diagram juga menujukan property dan operasi suatu class dan batasan yang terdapat dalam hubungan dengan suatu objek. Berikut merupakan class diagram dari aplikasi kamus Sunda-Indonesia.

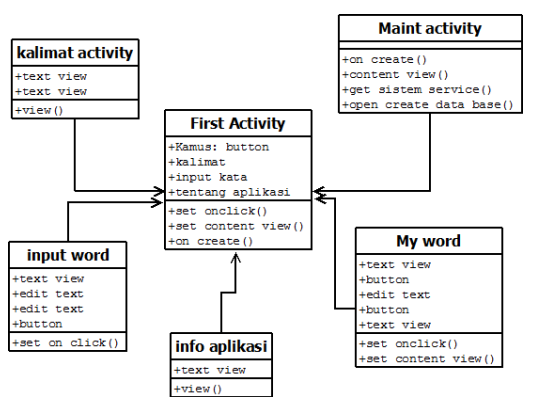

Gambar 4. 10 Class Diagram Struktur program

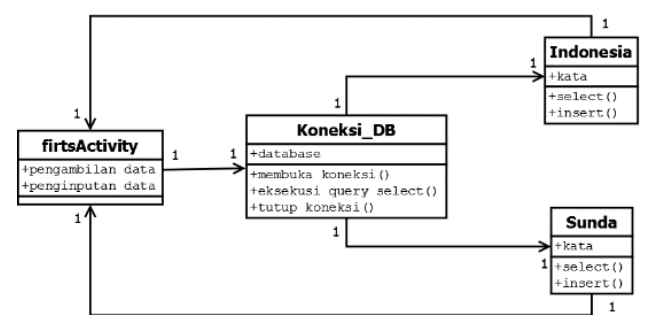

Gambar 4. 11 Class Diagram database

Tabel 4. 6 Tabel bahasa

\begin{tabular}{|l|l|l|}
\hline \multicolumn{1}{|c|}{ No } & \multicolumn{1}{|c|}{ Nama field } & \multicolumn{1}{c|}{ Type data } \\
\hline 1 & Indonesia & Varchar \\
\hline 2 & Sunda & Varchar \\
\hline
\end{tabular}

e. Desain Struktur Navigasi

Dalam desain navigasi ini menggambarkan alur dari suatu program yang terorganisasi dari seluruh elemen yang ada. Adapun struktur navigasi sebagai berikut.

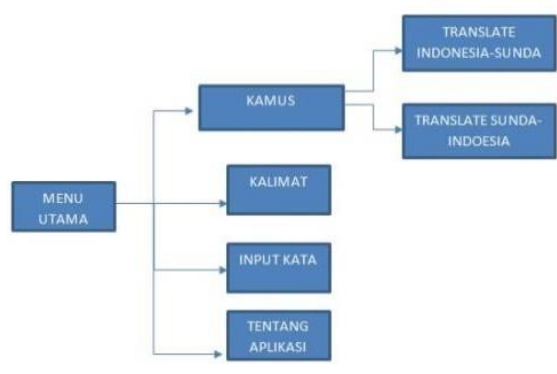

\subsection{Pengkodean Sistem}

Dari desain yang telah dibuat dan disetujui oleh pengguna, kemudian akan diterjemahkan kedalam suatu program perangkat lunak yang hasilnya yaitu perangkat lunak kamus sunda-indonesia pada perangkat android. kode program di buat menggunakan Java dan XML, database pada aplikasi menggunakan SQLite terlampir di program.

Dalam membangun perangkat lunak kamus sunda-indonesia, perangkat lunak yang digunakan adalah :

Tabel 4. 7 perangkat lunak yang digunakan

\begin{tabular}{|r|l|l|}
\hline No & Software & Kebutuhan \\
\hline 1 & Sistem Operasi & Windows 8.1 Ultimate 64- Bit \\
\hline 2 & Program Editor & $\begin{array}{l}\text { Android Studio 3.1 } \\
\text { Android SDK 4.1.2 (API 16) }\end{array}$ \\
\hline 3 & Image Editor & Adobe Photoshop CS3 \\
\hline 4 & Dukungan & JDK (Java Development Kit) \\
\hline
\end{tabular}


Adapun perangkat keras dalam membangun Aplikasi kamus bahasa Sunda-Indonesia pada platform android yaitu :

Tabel 4. 8 perangkat keras dalam membangun Perangkat Lunak

\begin{tabular}{|r|l|l|}
\hline No & \multicolumn{1}{|c|}{ Spesifikasi } & \multicolumn{1}{|c|}{ Kebutuhan } \\
\hline 1 & Processor & AMD E1 \\
\hline 2 & RAM & 4 GB DDR 3 \\
\hline 3 & VGA & Intel GMA 4500M, 3D/2D Graphics Accelarator, DirectX \\
\hline 4 & Harddisk & 500 GB \\
\hline 5 & Smartphone Andoid & Samsung galaxy E5 \\
\hline
\end{tabular}

\subsection{Instalasi}

Tahap instalasi ini merupakan instalasi dari package yang sudah berekstensi (.apk) dan diterapkan pada perangkat smartphone yang menggunakan sistem operasi Android. Serta mengimplementasikan antarmuka dari perangkat lunak yang dibangun. Berikut merupakan antarmuka perangkat lunak kamus sunda-indonesia pada platform android.

1. Menu aplikasi

Berikut merupakan menu utama di perangkat android dan icon perangkat lunak kamus sunda-indonesia

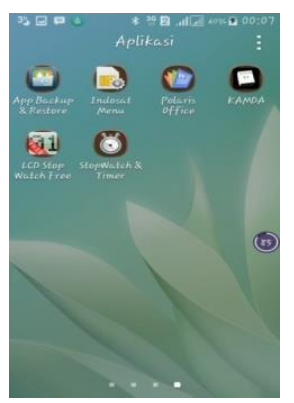

Gambar 4. 12 Gambar Menu Utama Android

Menu aplikasi merupakan tampilan menu yang ada pada android, jika perangkat lunak sudah diinstal pada perangkat smartphone android, maka perangkat lunak kamus sunda- indonesia ini akan terpasang pada menu utama pada perangkat smartphone android.

1. Menu utama

Berikut tampilan Menu Utama.

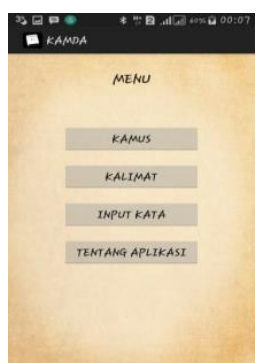

Gambar 4. 13 Tampilan Menu Utama

Menu Utama merupakan tampilan utama perangkat lunak, dimana pada tampilan ini terdiri dari empat menu utama yaitu diantaranya kamus, kalimat, input kata, tentang aplikasi. Dari empat menu utama tersebut akan menampilkan pilihan dan fungsi sesuai dengan yang ada pada menu utama.

2. Menu kamus

Berikut merupakan tampilan Menu kamus.

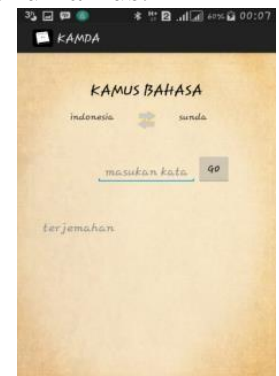

Gambar 4. 14 Tampilan Menu Kamus 
Menu kamus akan ditampilkan apabila menu kamus dipilih pada Menu Utama. Pada menu kamus terdapat pilihan diantaranya adalah bahasa indonesia ke bahasa sunda atau bahasa sunda ke bahasa indonesia. Di menu kamus ini terdapat juga inputan kata yang ingin di terjemahkan.

3. Menu kalimat

Berikut merupakan tampilan menu kalimat.

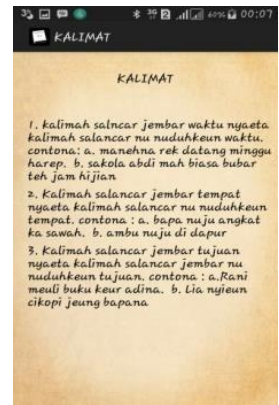

\section{Gambar 4. 15 Tampilan Menu Kamus}

Menu kalimat akan ditampilkan apabila menu kalimat di pilih pada menu Utama. Pada menu kalimat terdapat kalimat bahasa sunda.

4. Menu input kata.

Berikut merupakan tampilan input kata

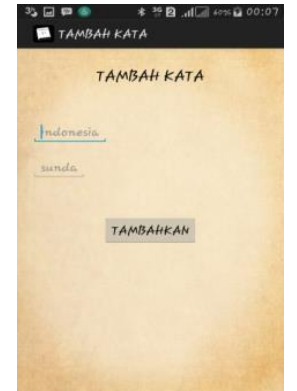

Gambar 4. 16 Tampilan Menu Input Kata

Menu input kata akan di tampilkan apabila menu input kata dipilih pada menu Utama. Pada menu input kata terdapat menu masukan kata yang ingin di tambahkan pada kamus bahasa sunda-indonesia.

5. Menu tentang palikasi

Berikut merupakan tampilan tentang aplikasi

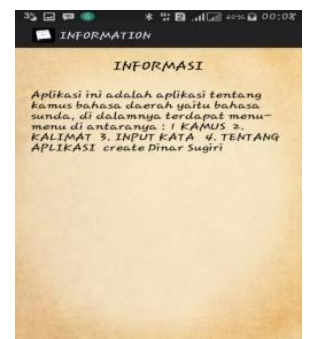

Gambar 4. 17 Tampilan Menu Tentang Aplikasi

Menu tentang aplikasi akan di tampilkan apabila menu tentang aplikasi di pilih pada menu Utama. Pada menu tentang aplikasi di jelaskan bagai mana penggunaan aplikasi dan apa saja yang di perlukan untuk menginstal aplikasi .

\section{KESIMPULAN DAN SARAN}

\subsection{Kesimpulan}

Kesimpulan dari penelitian ini adalah:

1. Aplikasi ini di bangun dengan menggunakan tools Android Studio dengan database SQLite sehingga kamus Sunda-Indonesia dapat di gunakan pada Android 4.0 ke atas.

2. Penerpan algoritma binary search di letakan pada pencarian data pada database.

3. Pengujian ini di lakukan terhadap Aplikasi dan juga user. Pengujian Aplikasi 
menggunakan black box dan white box. Sedangkan pengujian user menggunakan kuisioner dengan menggunakan rating scale dengan presentasi sangat baik $21,25 \%$, Baik 68,75\%, Cukup 10\% dan kurang 0\%

\subsection{Saran}

Dari Kesimpulan diatas, maka saran yang dapat dikemukakan agar menjadi lebih baik lagi, diantaranya :

1. Untuk penelitian selanjutnya disarankan untuk menambahkan validasi pada ke user pada menu input kata

2. Untuk penelitian selanjutnya disarankan untuk penambahan kalimat sesuai kata yang di cari.

\section{DAFTAR PUSTAKA}

Arifiyanto Hadinegro, N. A. (2013). perancangan aplikasi mobile untuk pengenala aksara jawa. jurnal teknik informatika, 5.

Arzan Muharom, R. c. (2013). pengembangan aplikasi sunda berbasis android menggunakan metode rapid aplication development (RAD). jurnal algoritma, 11.

Dwi eli kurniawan, R. s. (2013). Aplikasi kamus aneka bahasa daerah berbasis smartphone android.

jurnal teknoloki komunikasi, 5.

El-Masry, A. G.-W. (2011). Mobile information communication technologies adoption in developing countries. Idea Group Inc (IGI).

geber, A. (t.thn.). 2013.

Hardjono, R. (1999). Ungkapan bahasa inggris sehari-hari. jakarta: Gramedia Pustaka. Hip, D. R. (2011). Android studio.

Idin Baidillah, U. A. (2008). Direktori Aksara sunda Untuk Unicode. Bandung: Dinas Pendidikan Provinsi Jawa Barat.

Istiyanto, A. S. (2009). Mobile Learning. Prespektif \& Tantangan Pengembangan M-Learning, 87- 96.

Kadir, A. (2014). Audio. Dalam Pengenalan Sistem Informasi Edisi Revisi (hal. 45). Yogyakarta: Andi.

Kadir, A. (2014). Prototipe. Dalam Pengenalan Sistem Informasi Edisi Revisi (hal. 357).

Yogyakarta: Andi.

Ladjamudin, A. b. (2013). Perancangan (Design). Dalam Analisis Dan Desain Sistem Informasi (hal.

39). Yogyakarta: Graha Ilmu.

M.Salahudin, R. A. (2014). Rekayasa Perangkat Lunak . Dalam Rekayasa Perangkat Lunak Terstruktur dan Berorientasi Objek (hal. 25). Bandung: Informatika.

Nazruddin Safaat H. (2014). Pemograman Aplikasi Mobile Smartphone dan Tablet PC Berbasis Android. Bandung: informatika.

Nugroho, A. (2009). Rekayasa perangkat lunak menggunakan UML dan Java. Yogyakarta: CV Andi .

PH.D, R. S. (2002).

Prawirasumantri. (2007). bahasa sunda masa kini. Bandung: erlangga.

Priharyanto, I. (2012). Apllikasi kamus bahasa Indonesia-Jawa-Jawa krama berbasis android. jurnal informatika, 12.

Prihatna. (2014, June 28). Jenis Jenis Struktur Navigasi Pada Website. Dipetik Rachm

Hakim S, I. S. (2009). Mastering Java. Jakarta: Alex Media Komputindo.

Ridwan. (2010).

Roger S, p. (2002). pendekatan praktisi edisi 1 rekayasa perangkat lunak. yogyakarta: andi.

Rossa A S dan M Shalahuddin. (2014). Rekayasa Perangkat Lunak Terstruktur dan Berorientasi Objek. Bandung: Informatika. n Tablet PC Berbasis Android (hal. 6-9). Bandung: Informatika.

Safaat.H, N. (2014). DVM. Dalam Pemrograman Aplikasi Mobile Smartphone Dan Tablet PC Berbasis Android (hal. 4-5). Bandung: Informatika.

Sugiono. (2013).

Syafaruddin, J. n. (2013). sistem aplikasi kamus penerjemah bahasa indonesia lontara bugis berbasis metode binary search dan parsing tree. jurnal teknik, 1 .

T.Munawar, C. (2009). Panduan Baca Tulis Aksara Sunda. Bandung: Yrama Widya.

Triady, D. (2013). Os android dan poerkembanganya. Dalam D. Triady, Bedah Tuntas Fitur Android (hal. 1-2). Yogyakarta: Galangpress. 
Zuchridin Suryawinata, S. H. (2003). Bahasan teori dan penuntun praktis menerjemahkan. Yogyakarta: kanisius. 